improvised equipment, late in the course of the crisis. He had to work in ignorance of the earlier stages of activity and without any precise information of the normal condition of the islands. I'hese difficulties can only be avoided by the establishment of a regular observing system. In view of the likelihood that further crises will occur within the next few years, the Colonial Office has asked for recommendations in this direction. As the centres of activity are known to oscillate along the whole length of the arc, it is clearly undesirable for attention to be concentrated on the most recently affected island. Earthquake epicentres must be located wherever they might occur, and it is proposed that a single sensitive seismograph should be maintained on each of the major British islands, and the records collected for interpretation at a central office. The small shock recorders would form part of a mobile reserve of equipment which would be sent to the centre of any concentration of activity. Operations would be under the control of a full-time, scientifically qualified observer, who would make regular tours of inspection during quiet periods. Quite apart from the value which these observations would acquire in time of crisis, it is to be expected that they would provide important scientific information on the structure of the arc and on processes which are continuing underground. These recommendations have been accepted in principle and the assembly of the equipment has begun.

In conclusion, I desire to express my appreciation for the hospitality and assistance which I received from the Governor of the Leeward Islands (His Fxcellency Kenneth Blackburne), from the Administrator of St. Kitts (His Honour H. Burrowes), and from the Warden of Nevis (the Hon. E. A. Evelyn). Further thanks are due to those residents of St. Kitts and Nevis who housed and operated the instruments, particularly to $\mathrm{Mr}$. R. E. Kelsick and Mr. H. Hadden, who are continuing their services at the time of writing. Finally, I must express my gratitude to those people on many islands whose friendliness and hospitality did so much to enliven my stay in the Caribbean area.

${ }^{1}$ Willmore, P. I., Mon. Not. Roy. Astro. Soc., Geophys. Supp., 6, 129 (1950).

${ }^{2}$ Powell, C. F., Phil. Trans. Roy. Soc., A, 237, 1 (1938).

\section{FIBRES FOR PAPER-MAKING}

$\mathrm{T}$

HE scarcity and high cost of paper are matters of which everyone is painfully aware, even in a world of rising prices and shortages. They are, however, of special importance to the scientific worker because they affect the scientific publications on which he depends. Most learned and similar societies have been compelled within recent years to make considerable economies in their publication costs or to raise their subscriptions, or both; and although printing costs are one of the principal factors responsible, the paper question is also of great importance.

So far as paper in Great Britain is concerned, the price and availability of the fibrous raw materials used to make it are the controlling factors, so that the problem has both scientific and economic aspects. For these reasons the sixty-third general conference organized by the Technical Section of the British Paper and Board Makers' Association (Inc.), and held at Manson House, London, during March 27-28, should be of special interest to scientific workers of all denominations.

The subject of the conference was "Fibrous Materials for Papermaking - the Present Position and Future Possibilities", and the introductory paper dealing with the subject in a general way was by Sir Herbert Hutchinson, director-general of the Association. Sir Herbert's contribution was essentially factual, and it outlined clearly the problems that face the industry. Special emphasis was placed on the fact that, in recent years, of the world consumption of timber only about 8 per cent was in the form of wood pulp. Moreover, of the world consumption of wood pulp, only about 5 per cent is used in the United Kingdom, while in Canada alone 3 million tons of merchantable timber is destroyed by fire every year.

It is apparent that British needs are comparatively small in a very large world. Sir Herbert would not venture into the realms of prophecy, although he did go so far as to express the opinion that the materials used by the paper-making industry are not running out in a shrinking world. This general conclusion was, on the whole, supported by most of the other authors of papers and speakers.

It is as well, nevertheless, not to gloss over the potential seriousness of the situation. As one speaker pointed out, the present per capita consumption of paper and board ranges from about $400 \mathrm{lb}$. a year in the United States to only 2.4 in Asia; it is 116 in northern Europe. The United States figure is still rising, and, if it is even to be approached elsewhere in the world, a tremendous amount of raw material must be forthcoming; for example, a world-wide average increase of only $10 \mathrm{lb}$. per capita would require 20 million tons of raw materials.

The second and third papers were in many respects complementary, and they are conveniently considered together. The first, by L. G. S. Hebbs, provided a comprehensive approach to the problem of increasing cellulose supplies. In the other, I. G. Burns and J. Grant dealt principally with the potentialities in this connexion of esparto grass and straw, respectively.

The theme of Hebbs's paper, and of the speakers who supported it, was that considerable quantities of wood in one form or other are still available in various parts of the world. For example, there are the huge untouched forests of Central America and parts of Canada (where pulp production increased by 50 per cent between 1917 and 1950); there is the development of integrated forest industries on a sustained yield basis and advances in forestry management which could ensure supplies of wood in perpetuity; and there is also the prevention of the huge losses by fire. Much work, too, has been carried out on the utilization of types of wood (particularly hardwoods) hitherto believed to be unsuitable for purping purposes, and also on the use of thinnings, toppings and other forms of what has, in the past, been regarded as sawmill waste and, as such, burned. The possibilities of hardwoods are of special interest. In general, their lower average fibre-length makes them less suitable for use alone in paper than are the softwoods. However, with a proportion of softwoods they serve an excellent purpose in printing papers or for board production. In Australia the eucalypts are already the source of a flourishing pulp and paper industry; and there are large stands of eucalypts in South America and of wallaba in British Guiana. 
Some of these forests are not 'pure', in the sense that they consist of more than one species of tree. In the forests of British Guiana there are at least a hundred and twenty identified species; but fortunately not more than nine of these are present in such frequency that they have to be taken into account from the pulping point of view.

Hebbs's paper also dealt briefly with bagasse, bamboo, elephant grass, and other fibres which might be described as of local interest. The conclusion was reached that the contribution that such fibres can make is probably quite small, and insufficient to provide the large tonnage required to satisfy expanding world demand, although it would have undoubted value in many instances for local and specialized uses.

Burns and Grant emphasized the fact that esparto and straw have been closely associated together in Great Britain, because straw was used during the Second World War as an emergency papermaking material and was processed by those same mills which, before the War, made esparto papers. This was done merely because these mills alone had the necessary plant readily available in time of emergency, and it was therefore quite natural that they should use straw in the types of paper which they had formerly made from esparto.

Esparto is essentially a specialty fibre. Since its first use in 1861, it has established itself principally as a printing fibre by virtue of its capacity to produce paper having resilience to printing pressure, opacity, flatness, good register and, if suitably processed, freedom from 'fluffing' in the offset process of printing. It has attained this status as a result of long experience of manufacture in Great Britain and, indeed, it is not used to any appreciable extent elsewhere in the world.

The esparto supply position is fairly clear-cut. The grass is grown over wide though restricted areas in North Africa and to some extent in the south of Spain, and it seems unlikely for geographical reasons and because of the labour position that there will be any considerable increase in world supplies of paper from this source. Even assuming attractive market conditions, normal weather, absence of political unrest and extended exploitation of the Libyan fields, any increase in production would probably not amount to more than about 50,000 tons a year, which is equivalent to about 21,000 tons of pulp ready for papermaking. As the proportion of esparto in relationship to wood pulp imported into Great Britain has varied only between 17 and 25 per cent since 1913 , and as the maximum annual import of esparto during this period was less than 350,000 tons, it is obvious that esparto cannot be counted on to increase markedly British supplies of cellulose. Nevertheless, it should continue to occupy the same privileged position as a specialty fibre that it has held for nearly a hundred years.

So far as Britain is concerned, the straw position is much more debatable. The reason for the association of straw with esparto grass has already been explained, but there are signs of the development of a natural differentiation since the War. Research along several different lines in various parts of the world has indicated plainly that the direct pressure digestion of straw with caustic soda (as used for esparto grass) is not the best method from the point of view of either quality or cost. It is too drastic, and not sufficiently selective, because in resolving the more resistant parts of the plant the true cellulose is overcooked. 'The resulting pulp is 'slimy', shortfibred, involves high chemical consumption and generally is not greatly liked by either the papermaker or user. These were all drawbacks which could be accepted in war-time, when there was no alternative.

These unsatisfactory methods of manufacture are likely to be replaced by more selective forms of digestion. One continuous process already in practical operation involves a relatively light digestion with alkali followed by treatment with gaseous chlorine. The chlorinated constituents are then dissolved in alkali, and the resultant pulp, if bleached and screened, is satisfactory in colour and cleanliness. The character of the resulting pulp approaches a standard between ordinary wood pulp and straw made by the 'esparto process'. The yields, and chemical costs too, are better than those of the latter, but the process has the great disadvantage that the alkaline waste liquors cannot be recovered and must be discharged as effluent. This is objectionable on the grounds of economy and, of course, unless the mill is favourably situated, on the grounds also of river pollution.

Promising results have also been obtained by the use of neutral sodium sulphite or of sodium sulphide in the digestion liquors, the latter method following on the well-known kraft process for the manufacture of wood pulp. The general procedure is the same as with the standard soda cook; but improved yields, lower chemical consumption and a higher quality are obtained. The neutral sulphite process is particularly good where cheap supplies of that chemical are available.

Another and more recent process which is attracting a good deal of attention comprises the mechanical disintegration of the straw near the boiling point of water, without pressure, in dilute alkali, followed by screening to remove the coarse impurities, and bleaching by the type of three-stage bleaching process commonly used in Scandinavia and North America for bleaching wood pulp. This involves chlorination, an alkaline wash, and a hypochlorite bleaching stage. The results appear to be extremely promising. The high yields of 48 per cent of bleached pulp claimed are attributed to the fact that the pulp contains relatively high proportions of hemicelluloses, which the more drastic pressure-processes largely eliminate.

However, promising as these new digestion methods are, they can be only part of the story so far as Great Britain is concerned. 'The vital consideration is, of course, the availability of the raw straw. Unfortunately, various opinions, each carrying a measure of authority, differ widely; and although the statistics indicate that there should be ample supplies, in actual fact from time to time during the past few years there have been shortages, broken up, it is true, by periods of comparatively low price and plenty. In 1951 nearly seven million tons of straw were grown in Great Britain. After eliminating the $2 \frac{1}{2}$ million tons of oat straw used principally for feeding cattle and 250 thousand tons used for bedding, thatching, clamping potatoes, etc., there is a residue of some 4 million tons for 'other farm purposes' and paper-making and packaging. The difference of opinion arises as to the proportion of this which could be transferred from 'other farm uses' to papermaking. Many farmers maintain that return of the straw to the land is an essential feature of good husbandry for which there is no substitute. Others argue that synthetic fertilizers and other forms of 
modern tillage produce as good results, and work in the United States has even indicated that straw left on the land may be detrimental to the subsequent growth of certain leguminous and forage crops. Several speakers expressed the belief that increased co-operation between the farming industry and the straw-pulping industry could make much more straw available for the latter, and so initiate a new and valuable national pulping industry.

The next paper, by H. R. Blanford, dealt with forestry in relation to paper and board, and was an excellent survey which confirmed in detail the general views sot out above. J. Macdonald then dealt with British woodlands and their production, and as such his paper was also of great general interest. However, it led to the inevitable conclusions that in Britain the surplus land is needed too badly to grow food to enable the existing forests to be extended; and that the present forest-wood is either unsuitable for pulping, or else is needed for other more urgent purposes. No indigenous woodpulp industry therefore seems likely in Britain.

The final paper was an authoritative contribution from the Mead Corporation (United States) dealing with the removal of ink from waste paper. Considerable technical progress has been made in this direction; but again, so far as Great Britain is concerned, the matter hinges around the supplies of waste paper available, and this point was dealt with in a supplementary paper by $\mathrm{S}$. F. Smith. Apart from imported waste paper, supplies in Britain of this material must necessarily be limited by the production of good paper, although the collection of waste paper continues to be of the greatest importance as an economy measure. It is interesting to note that the waste paper collected, expressed as a percentage of the total consumption of paper and board, has never been so high as in 1942 , when it was 61 per cent. During 1949-51 it ranged from 28-31 per cent as against 20 per cent in 1939 . Since the figure for 1951 corresponds only to about one million tons, it seems that there is still much room for improvement here. This point, and the danger of fluctuations between shortages and excesses, and means of evening them out, were emphasized by several speakers.

In the summing up which concluded the conference, common ground was shared by most speakers who held the view that, owing to sudden increases in demand (due to factors such as post-war development and rearmament, and accentuated by economic and distribution difficulties), the world in general, and Great Britain in particular, is at present experiencing a serious pulp shortage. The supplies of fibrous material existing in the world (especially of wood) should, however, certainly be sufficient to satisfy the immediate demand could they be made available. It is highly probable, moreover, that as education develops (particularly in Asia) pulp supplies can be stepped up to meet the increasing demand for paper, although temporary shortages may arise, just as trade cycles cause booms and slumps in other commodities. For all this the importance of vegetable fibres other than of wood should not be overlooked or even minimized, though quantitatively their possibilities may be less. Indeed, it seems certain that indigenous short-fibred plants such as straw, bagasse, bamboo, etc., will play a vital part in bridging the gap in various parts of the world, especially if the promise held out by new developments in pulping methods is realized.

Juirus Grant

\section{EAST AND WEST IN SCIENCE}

SYMPOSIUM of the British Society for the History of Science was held on April 17 to discuss "Historical Scientific Contacts between East and West". 'This topic is attracting increasing attention from historians of science; it was an important theme of the Sixth International Congress of the History of Science held at Amsterdam in 1950; it is to be a prominent theme of the next year's conference at Jerusalem.

The present symposium was organized by $\mathrm{Mr}$. F. H. C. Butler and included an important paper by Dr. Joseph Needham on Chinese mechanical sciences. The president of the Society, Dr. F. Sherwood Taylor, took the chair for the afternoon session, which was concerned especially with Arabic science. Chinese influences were discussed in the evening session, when Prof. J. R. Partington, a vice-president, took the chair:

The mysterious numbers such as $1,3,5,8,28$, which so often play an important part in alchemy (as is evident in the recent work of Kraus), were discussed by Dr. H. E. Stapleton in his paper on "Possible Sources of the Numbers on which Jabirian Alchemy is Based". He showed that the numbers could have been derived by magic squares or by the areal measurements of Babylonian ziggurats, and hinted that possibly the magic square was itself in origin a formula concealing temple measurements; such an idea might account for the magical potency with which it was regarded.

A discussion by Dr. A. Armitage and others followed; but no conclusive evidence appeared to be available to settle the various interesting problems raised. Dr. Sherwood Taylor pointed out that Arabic efforts to express all elements in numbers may seem futile to us until we remember that modern physicists are doing very much the same thing.

Dr. D. M. Dunlop (Cambridge) then spoke on "John Mesue and his Work". John Mesue is little known to-day, but was extravagantly praised during the Renaissance when both his genuine work and a mysterious Latin corpus (associated with a mythical Mesue Junior) were ranked very highly. An investigation of the Arabic biographies shows that the real John Mesue (Yuhannā b. Mâsawaih) belonged to the early Baghdad phase of Arabic science in the early ninth century. His father had been employed in a subordinate capacity at Jundī-Sābūr ; although unable to read, the clinical experience received there enabled him, after he had moved (c. 790) to Baghdad, to gain the confidence of the Caliph Harūn ar-Rashid. Mesue's mother, a Slav, had been a slave-girl, but at Baghdad the young son John received a good medical education (under Jibrīl b. Bukhtyashū') and rapidly rose to fame and fortune, living in the suburb Dâr ar-Rum (Abode of the Greeks) and being considered one of the leaders of the Christian community in the city.

Many anecdotes are reported of his majlis (assembly), a combination of lecture-room and consultinghour; but they reveal more of his wit than his methods - although it is evident that examination of urine and feeling the pulse were the standard clinical preliminaries. Freer perhaps from superstition than Galen's work, his "Axioms", written c. 830, emphasize common sense and moderation; he wrote a book (now lost) on the dissection of an ape which had been brought to the court in A.D. 835 by a visiting Abyssinian prince. His pupil, Ḥunain b. Ishāa, from 